\title{
Directed Reading and Thinking Activity as a Pedagogical Strategy on Learners' Reading Abilities in Kiswahili Language in Primary Schools, Bungoma County, Kenya
}

\author{
Sikolia Cleophas Kalabai*, Florence Abuyeka Miima, Samson Hossana Ondigi \\ Department of Educational Communication and Technology, Kenyatta University, Kenya
}

Received September 8, 2020; Revised May 17, 2021; Accepted June 6, 2021

\begin{abstract}
Cite This Paper in the following Citation Styles
(a): [1] Sikolia Cleophas Kalabai, Florence Abuyeka Miima, Samson Hossana Ondigi , "Directed Reading and Thinking Activity as a Pedagogical Strategy on Learners' Reading Abilities in Kiswahili Language in Primary Schools, Bungoma County, Kenya," Universal Journal of Educational Research, Vol. 9, No. 7, pp. 1353 - 1358, 2021. DOI: 10.13189/ujer.2021.090701.
\end{abstract}

(b): Sikolia Cleophas Kalabai, Florence Abuyeka Miima, Samson Hossana Ondigi (2021). Directed Reading and Thinking Activity as a Pedagogical Strategy on Learners' Reading Abilities in Kiswahili Language in Primary Schools, Bungoma County, Kenya. Universal Journal of Educational Research, 9(7), 1353 - 1358. DOI: 10.13189/ujer.2021.090701.

Copyright $@ 2021$ by authors, all rights reserved. Authors agree that this article remains permanently open access under the terms of the Creative Commons Attribution License 4.0 International License

\begin{abstract}
Reading is a language skill which is very important in almost all aspects of life. It is used in education and other daily activities. Therefore, reading is a critical skill which should be taught appropriately in schools. Despite this, many learners in primary schools cannot read the grade-level materials written in Kiswahili. This is attributed to the failure of the conventional strategies to promote reading. To find the solution to this problem, the current study investigated the influence of DRTA on the learner's abilities in reading Kiswahili as L2 and to establish its influence on the learner's reading abilities on the basis of gender. This was an experimental study that adopted both the Solomon Four Group and qualitative designs. Purposive sampling was used to select four primary schools from which 72 grade four learners and 4 teachers of Kiswahili were sampled. The stratified and random sampling techniques were used to select them. The data were collected by the pretest and posttest and analyzed by the ANOVA. The results indicated that the DRTA had more influence on the learner's reading abilities than the conventional strategies. However, the DRTA didn't cause any significant difference in the performance of boys and girls in reading. The study recommends that the teachers of Kiswahili adopt DRTA in teaching reading
\end{abstract}

in the middle classes where learners begin learning by reading. The teachers can also use the DRTA in teaching other language skills and learners who lack interest in reading or have reading difficulties.

Keywords Directed Reading and Thinking Activity, Comprehension Kiswahili Language, Strategy

\section{Introduction}

Reading is a language skill which is taught in primary schools. It is taught to equip the learner with the skills necessary in succeeding in education. The learner requires the skill to gather, understand, analyze and apply information in examinations [1]. Reading is the basis for learning and succeeding in education [2]. The importance of reading is not limited to education. People use it to understand medical prescriptions, newspapers, labels, directions, fill job application forms and for pleasure [1], [2], [13]. The people who read for pleasure broaden their vocabulary, general knowledge and understanding of the culture of the native speakers of the target language [26]. 
So reading is critical in almost all aspects of life. The curriculum developers included it in the primary schools' syllabus to ensure that the learners are taught how to read. However, many L2 learners find reading more difficult to learn than other language skills. The reason is that it involves several cognitive processes which cannot be mastered easily by the L2 learners [12]. Consequently, some of them fail to learn it and end up performing poorly in class. It is worse if the affected learner is in grade two. Glende [16] and Torgesar et al [36] say the learners who fail to read independently by the end of first or second grade, perform poorly in the subsequent classes unless the teachers intervene in time to improve their reading skills.

Kiswahili is taught in primary schools in Kenya as L2 and examined at grade 8. The marks which the learner scores in Kiswahili contribute to his/her over role examination results. The Ministry of Education bases on the over role results to determine the kind of high school the learner should join - national, county or sub-county. Many learners aspire to join national or county high schools because they have adequate teaching/learning facilities which enable them to excel in the form four examinations and join universities. So the learner's performance in Kiswahili at grade 8 is critical in getting admission in a better high school. However, research has indicated that Kiswahili is performed poorly in many primary schools in the country. The main reason is that many learners' cannot read the grade level materials. This is attributed to the ineffective methods/strategies which teachers use in teaching reading [11],[37]. They use conventional methods/strategies which encourage memorization of facts/ideas and hardly involve the learner in the learning process [11]. Maimuna, Ibrahim, Muslim and Jarudin [22] said, “...the use of approaches, methods and techniques of reading that are not appropriate is one of the determinants of the lack of maximum achievement of the learning goals of reading in schools"'. To find the solution to this problem, the teachers of Kiswahili should change the strategies and use the most appropriate ones in teaching reading. Therefore, teachers should change the strategies by intensifying learner participation in reading activities. In addition to this, learners should be taken through the three steps of reading process which involve activities in pre-reading, while reading and post reading phases [8]., [23]. In this connection, the DRTA can be suggested for teaching reading Kiswahili as L2

The DRTA was developed by Russeell Stauffaur in 1969 to improve the learner's reading skills [23]. Unlike other instructional strategies, the DRTA is regarded as a strong model for teaching reading which helps the learners to be thoughtful and independent readers [40].The strategy also develops their predicting, critiquing, and monitoring skills. These skills are critical in understanding a text. Lastly, it makes reading more interesting and motivating hence facilitating comprehension [3], [25].

Many studies investigated the influence of DRTA on the learner's abilities in reading $\mathrm{L} 2$. The investigations were conducted in foreign countries like Iran [23] and Indonesia [40] and involved the students who were learning English as a L2. However, those studies had contradicting findings. Some say it influences the learner's reading abilities [21], while others contradict [40]. There was little information about the same strategy working for Kiswahili. Kiswahili is a 'Bantu' language with a different structure with that of English. There was need for another study to be conducted in Kenya and involve the learners of Kiswahili as L2 with the view of establishing whether DTRA could influence their reading abilities and whether its influence on the boys' reading abilities differed from that of girls due to their differences in the learning styles [22].

\section{Methodology}

This was an experimental study which adopted the Solomon Four Group and qualitative designs. The Solomon Four Group Design was adopted to explain the causal-effect relationships of the variables under study [25]. Seventy two learners from grade four participated in the study. They were divided into four groups $-E_{1}, E_{2}, C_{1}$ and $\mathrm{C}_{2}$. The experimental groups were $\mathrm{E}_{1}$ and $\mathrm{E}_{2}$ while the control ones were $C_{1}$ and $C_{2}$. The first experimental group $\left(E_{1}\right)$ and the first control $\left(C_{1}\right)$ were pretested and later post-tested. The post-test involved all the four groups. The table below illustrates this design.

Table 1. Solomon Four-Group Design

\begin{tabular}{|c|c|c|c|}
\hline Group & Pre-test & Treatment & Post-test \\
\hline $\mathrm{E}_{1}$ & $\mathrm{O} 1$ & $\mathrm{X}$ & 02 \\
\hline $\mathrm{C}_{1}$ & 03 & & 04 \\
\cline { 1 - 1 } $\mathrm{E}_{2}$ & & \multirow{2}{*}{$\mathrm{X}$} & 05 \\
\hline $\mathrm{C}_{2}$ & & & 06 \\
\cline { 1 - 1 } & & & \\
& &
\end{tabular}

Key: $\mathrm{E}_{1}$ experimental group 1; $\mathrm{E}_{2}$ experimental group 2; $\mathrm{C}_{1}$ control group 1 ; $\mathrm{C}_{2}$. control group 2.; $\mathrm{X}$ treatment, 01, 04-pre-test; 02,03,05,06post-test.

The qualitative research design provided information about the mean differences between the experimental and the control groups.

The learners in both the experimental and the control groups had similar characteristics. They came from the same rural environment and learnt Kiswahili as a L2. Secondly, the learners were of the same age and ability. Research indicated that the learner's age affects his/her language acquisition. The younger learners are better at L2 acquisition than the late starters such as adolescents [17]. Therefore, the results of the current study could have been affected negatively if the grade four had young and old learners (adolescents).

\section{Area of Study}

The study was done in the selected primary schools in 
Bungoma County in Western Kenya. Bungoma was selected because it performs poorly in the grade 8 national examinations of Kenya Certificate of Primary Education (KCPE). The county is currently experiencing a problem of how to improve the reading instruction since the dominant convectional strategies/methods had failed to promote reading [11]. There was need for the teachers to apply the research-based strategies which directly and explicitly teach learners the reading skill [32].

\section{Instrument}

The study used two comprehension tests - a pre-test and post-test. The tests had comprehension passages which were extracted from two grade four course books. The passage for the pre-test was extracted from Kiswahili Mufti [39] and the one for the post-test came from Kiswahili Sanifu [5]. Each test had twelve multiple choice questions. The questions were twelve because the learners were young and their concentration span was short [24]. Therefore, they could not be subjected to long tests.

\section{Sample and Sampling Procedure}

Purposive, stratified and simple random sampling techniques were used to get 72 learners (36 girls and 36 boys) and 4 teachers of Kiswahili (1 female and 3 males). The purposive sampling was used to select four primary schools in which the study was conducted. The four schools were selected because they used to perform poorly in Kiswahili in the national examinations of KCPE. Out of the four schools, two were experimental and the remaining two were control. The stratified sampling was used in putting the learners into two groups (girls and boys) to give each member of the group an equal chance of taking part in the study. Thereafter, the sample was randomly picked to get $30 \%$ of the learners from each group whose marks were used as data. The study used 30\% because it was considered as the minimum sample size [38].

\section{The Findings and Discussion of the Study}

The purpose for this study was to investigate the influence of the DRTA on the learner's abilities in reading Kiswahili as L2. To achieve this purpose, the learners in group $\mathrm{E}_{1}$ and $\mathrm{C}_{1}$ were pre-tested and later post-tested. The reason for pre-testing was to provide a baseline for comparison. The results for the pre-test were presented in table 2.

Table 2. The Pre- test Results

\begin{tabular}{ccccc}
\hline Group & No & Mean & Mean Difference & Sign \\
\hline $\mathrm{E}_{1}$ & 18 & 33.84 & 1.82 & 0.062 \\
\hline $\mathrm{C}_{1}$ & 18 & 31.92 & & \\
\hline
\end{tabular}

The results in the table above showed that the learners in group $\mathrm{E}_{1}$ had a mean of 33.84 and those in group $\mathrm{C}_{1}$ had a mean of 31.92. The difference between the groups' means was 1.82 . The 1.82 meant that there was a difference in the performance between the two groups. There was an inferential (ANOVA) analysis on the two means to establish if the difference was statistically significant. The results were $0.062(\mathrm{p} \leq 0.5)$ meaning that the difference was small and statistically insignificant. The difference was statistically insignificant because the learners used similar techniques they learnt before the study in answering comprehension questions.

The learners in $E_{1}$ and $E_{2}$ were taught by the DRTA and those in $\mathrm{C}_{1}$ and. $\mathrm{C}_{2}$ were taught by the conventional methods like read aloud. Later, all the four groups $\left(E_{1}, E_{2}\right.$, $\mathrm{C}_{1}$ and. $\mathrm{C}_{2}$ ) were post-tested. The results were indicated in table 3 .

Table 3. Scores for the Post-test

\begin{tabular}{cccc}
\hline Group & No & Mean & $\begin{array}{c}\text { Mean } \\
\text { Difference }\end{array}$ \\
\hline $\mathrm{E}_{1}$ & 18 & 37.84 & 4.84 \\
\hline $\mathrm{C}_{1}$ & 18 & 33.00 & \\
\hline & & & 4.97 \\
\hline $\mathrm{E}_{1}$ & 18 & 36.24 & \\
\hline $\mathrm{C}_{1}$ & 18 & 31.27 & \\
\hline
\end{tabular}

The table above showed that $\mathrm{E}_{1}$ had a mean of 37.84 while $\mathrm{C}_{1}$ had a mean of 33.00. The difference between the two means was 4.84 . The means for $E_{2}$ and $C_{2}$ were 36.24 and 31.27 respectively. The experimental groups' means were: $E_{1} \quad(M=37.84)$ and $E_{2}(M=36.24)$. The control groups had the means: $C_{1}(M=33.00)$ and $C_{2}(M=31.27)$. The mean difference between the two control groups was 1.73. There was an inferential (ANOVA) analysis on the means of $E_{1}$ and $C_{1}$ to determine if the difference between them was statistically significant. The result was 0.03 $(\mathrm{p} \leq 0.5)$ which meant that the difference was big and statistically significant. The study analyzed the means for $E_{1}$ and $C_{1}$ because they were the main experimental and control groups respectively.

The statistics above showed that the learners in group $E_{1}$ performed much better than those in group $C_{1}$ in the post-test. The better performance was attributed to the influence of the DRTA on the learners' reading abilities. The DRTA had many learning activities like predicting the text's message, reading to confirm or revise the predictions and summarizing the message of each paragraph read. Those activities made the learners to be keen in reading hence performing better in the tests given. The learners' better performance was in line with the views of Price [29] that the learners display positive learning behaviours when engaged in a variety of learning activities. The results also confirmed the cognitive view about reading that reading is an active process in which the reader is a participant [33]. The reader participates by 
interacting his/her reading strategies, prior knowledge and the text to construct the meaning [9].The interaction should be smooth and involve all the components [32].

The $E_{1}$ results were also better because the learners used pictures in predicting and confirming or revising the predictions. The pictures aroused their interests and motivation in reading which enabled them to recall the message read [6], [18]. In addition to that, the pictures presented information vividly and in summary making it easier for the readers to comprehend the message [30]. According to Sadiq [34], a photograph is worth a thousand words through which a complex idea can be conveyed with just one still. Lastly, the teachers of $E_{1}$ used many questions compared to those in $\mathrm{C}_{1}$ in teaching the learners how to use the DRTA in reading Kiswahili. The questions guided the learners to predict the message and focus on the important information in the text hence getting better results. The language experts are in agreement that the DRTA is a powerful and effective instructional strategy when teachers guide students in predicting and checking the predictions after reading [27]. The learners in $\mathrm{C}_{1}$ were taught by the conventional strategies/ methods which didn't have many questions to engage the learner fully in the learning process [35]. They were teacher-centred and only emphasized on the learners memorizing the message read [37]. The results of this study were in line with the findings of Marlindawati [21] who found out that DRTA had more influence on the learner's reading abilities than the conventional strategies. However, they differed with the findings of Yuliana [40] who found out that the convectional strategies didn't differ with the DRTA in influencing the learner's abilities in reading a $\mathrm{L} 2$.

The study also investigated the influence of the DRTA on the learner's reading abilities on the basis of gender. It pre-tested and post-tested the learners in $E_{1}$ and $C_{1}$ and their scores analyzed on the basis of gender. The results were presented in table 4 and 5 below.

Table 4. The Pre- test Results Based on Gender

\begin{tabular}{cccccc}
\hline Group & Gender & No & Mean & $\begin{array}{c}\text { Mean } \\
\text { Difference }\end{array}$ & Sign \\
\hline E1 & Female & 9 & 53.8 & 1.8 & 0.075 \\
\hline & Male & 9 & 52.0 & & \\
\hline \multicolumn{7}{c}{ C1 } & Female & 9 & 53.2 & 1.5 & 0.07 \\
\hline & Male & 9 & 51.7 & & \\
\hline
\end{tabular}

An examination of the results in table 4 showed that the means for the girls and boys in group $\mathrm{E}_{1}$ were 53.8 and 52.0 respectively. Their mean difference was 1.8 . The inferential (ANOVA) analysis was conducted to establish whether the difference between the girls' mean and boys' mean was statistically significant. The results were 0.075 meaning that the difference was small and statistically insignificant.
The girls in $\mathrm{C}_{1}$ had a mean of 53.2 and the boys had a mean of 51.7. The inferential analysis was conducted to establish if the difference between the two means was significant. The results were 0.07 meaning that the difference was small and statistically insignificant.

Table 5. The Post-test Results Based on Gender.

\begin{tabular}{ccccc}
\hline Group & Gender & No & Mean & $\begin{array}{c}\text { Mean } \\
\text { Difference }\end{array}$ \\
\hline E1 & Female & 9 & 58.6 & 1.2 \\
\hline & Male & 9 & 57.4 & \\
\hline C1 & Female & 9 & 54.5 & 1.0 \\
\hline & Male & 9 & 53.5 & \\
\hline
\end{tabular}

The results in table 5 showed that the girls in $\mathrm{E}_{1}$ got a mean of 58.6 and the boys got a mean of 57.4. Therefore, the mean difference between them was 1.2. In group $C_{1}$, the girls got a mean of 54.5 and the boys got a mean of 53.5. The difference between their means was 1.0.

Study also compared the girls' performance in $E_{1}$ and $C_{1}$. The results showed that the girls in $E_{1}$ had a mean of 58.6 and those in group $C_{1}$ had a mean of 54.5. The inferential analysis was conducted to establish whether the difference between the girls in $\mathrm{E}_{1}$ and $\mathrm{C}_{1}$ was statistically significant. The result was 0.042 which meant that the difference was statistically significant. The boys in $\mathrm{E}_{1}$ got a mean of 57.4 and those in $\mathrm{C}_{1}$ got a mean of 53.5. The inferential (ANOVA) analysis on the means of the two groups of boys $\left(E_{1}\right.$ and $\left.C_{1}\right)$ was 0.048 . The 0.048 showed that the difference was big and statistically significant.

The statistics above indicated that girls were better than boys in reading Kiswahili as L2. That was attributed to the DRTA having had more influence on girls than boys. Secondly, girls were more able to identify the general and specific information in the text than boys [4]. Most of the questions in the pre-test and post-test tested the learner's abilities to identify both specific and general information in the texts hence giving girls an advantage over boys. Furthermore, the DRTA had many learning activities like discussion and writing which favoured girls than boys. The study of Dickey [15] indicated that girls perform much better than boys when the teachers use the methods/ strategies that emphasize on speaking (small discussions, role playing etc.) and writing. The results of this study were in line with findings of [7], [14], [19] who indicated that girls are better than boys in reading $\mathrm{L} 2$.

\section{Conclusion and Recommendation}

This study investigated the influence of the DRTA on the learner's abilities in reading Kiswahili. The results showed that the DRTA had more influence on the learners than the conventional strategies. The DRTA didn't cause any difference between the performance of girls and boys 
in reading Kiswahili as L2.

This study recommends to the teachers of Kiswahili to integrate the DRTA in teaching reading in the intermediate classes where the pupils start learning by reading and the assessment is formative. The teachers can also use the strategy in teaching reading when other strategies fail to achieve the intended objectives. In addition to that, the teachers can use the DRTA in teaching reading Kiswahili in single-sex and mixed schools because it doesn't favour the learner's gender. Furthermore, the study recommends that the teachers of Kiswahili use the DRTA in teaching the learners who lack interest in reading or have difficulties in reading Kiswahili as a L2. Finally, the DRTA can be used in teaching other language skills like listening, speaking and writing which are important in learning Kiswahili language.

This experimental study involved a small number of participants. They were 72 grade four pupils and 4 teachers of Kiswahili. A similar study with more participants can be conducted in a different geographical area and compare its results with those of the current one. This study was conducted in grade four. Its results cannot be used to generalize the influence of the DRTA on the learner's reading abilities in other classes. Therefore, another study can be conducted in other classes to establish how the DRTA influences the learner's abilities in reading Kiswahili.

\section{REFERENCES}

[1] Almutairi, N.R. Effective Reading Strategies for Increasing the Reading Comprehension Level of Third- Grade Students with Learning Disabilities. http://scholarworks.wmk.edu/des ertation3247. Retrieved on June 12. 2019

[2] Andzaye, C.A \& Ikwen, E.U.. Developing Reading Skills Among Pupils. www.academicstars.us/uploadfile/picture/20 15. Retrieved on 27/8/2018.

[3] Andiriani, D. The Influence of Reading Comprehension Achievement at the Eighth Grade Students of SMP Muhammadiyah1 Rawa Bening By Using DRTA and KWL Strategies. Tell-Us Journal. Vol.2, Issue 2, pp. 7-19 December 2016. DOI:10.22202/tus.2016.v2i2.1316

[4] Arellalo, M.D.C. Differences in Reading Comprehension Achievement in English as a Foreign Language in Compulsory Secondary Education. http://dialnet.unirioja.es/ descargo/articulo/4353124 Retrieved on 10/11/2018

[5] Bakhressa, S. K., Islam, I. K., Waititu. F.G \& Ali, F.A. Kiswahili Sanifu. Nairobi: Oxford University Press. 2005 (35-37).

[6] Bamid, M.S. Factors Responsible for Poor Academic Performance among Primary School Pupils. https://www.academic.edu/315187/Factors RESPONSIBLE _FOR_ POOR_ACADEMIC_ PERFORMANCE _AMONG _PUBLIC_PRIMARY _SCHOOL_PUPILS. Retrieved on June 21. 2019.
[7] Bonomo, V. Gender Matters in Elementary Education. https:files.eric.ed.gov/fulltext/E1895692pdf. Retrieved on July 27.2020

[8] Cartwright, N.S. Teachers Attitudes on Student Performance. http://www.personal.psu.edu/bfr3/blogs/asp/2012. Retrieved on 5/7/2020

[9] Connors-Tadros, L. (2014). Definitions and Approaches to Measuring Reading Proficiency.www.caelo.org/wp-context /uploads/2014/05ceolo-fast-fact-reading-proficiencypdf

[10] Cotter, J. Understanding the Relationship between Reading Fluency and Reading Comprehension: Fluency Strategies as a Focus for Instruction. https://fisherpub.sjfc.edu/education _FTD_masters/224. Retrieved on 26/11/2010

[11] County Government of Bungoma. Task Force Report on Education in Bungoma County.2014. pp. 25-34

[12] Davis, J. About Reading Theories in Elementary Schools. http://voices.yahoo.com/about-reading-theories-elementary school. Retrieved on6/11/2012

[13] Decker, M. To Read or Not to Read. A Comparative Study of Effective Reading and Methods of Teaching Reading. digitalcommons.liberty.edu $>$ cgi $>$ viwcontent.PDF. Retrieved on 24/6/2020

[14] Devolli, A. Gender Differences in Reading Comprehension Skill.

http://www.dspace.epoka.edu.al/.../Ardita\%20Devolli/\%20a nd\%20Behlul\%20Brestovc\%20. Retrieved on September 4. 2019

[15] Dickey, M.W. Gender Specific Instructional Strategies and Student Achievement in $5^{\text {th }}$ Grade Classroom. http://scholarcommons.sc.edu/etd/2624. Retrieved on July 3.2020

[16] Glende, L. Vocabulary and World Study to Increase Comprehension in Content Areas for Struggling Readers. http://fisherpubsjc.edu/education.ETD. Retrieved on 23/5/2019

[17] Hu, R. The age Factor in Second Language Learning. Theory and Practice in Language Studies, Vol. 6. No11.pp 21642168, 2016. www.academypublication.com $>$ article $>$ downlo $-\mathrm{d}$.

[18] Jandhyala, D. Visual Learning: 6 Reasons Why Visuals are the Most Powerful. https://elearningindustry.com/visual-lea rning-6-reasons-visual-powerful-aspect-learning. Retrieved on $24 / 5 / 2020$

[19] Madoda, C. Gender Differences in the Reading of Comprehension in Grade Three Rural Learners in South Africa. International Journal of Education Sciences. Vol.13. no.2 (247-254) 2016. DOI: 101080/097511 22 2016.11890458.

[20] Maimuna, Nurdin Ibrahim, Suyitno Muslim, Jarudin. The Influence of Instructional Models and Learning Styles on the Ability to Read to Understand. Universal Journal of Educational Research. Vol. 8. No 3A pp. 42-47, 2020. DOI:10.13189/ujer.2020.081406

[21] Marlindawati, H. The Influence of Using DRTA Towards Students Reading Comprehension at the $8^{\text {th }}$ Grade. http://www.respository.radenintan.ac.id/364/1/SKRIPSIPD F_NW.pdf.Retrieved on June 14.2019 
[22] Marianne, H. Intermediate Teaching Strategies. htt://teachingstrategiesofintermediate.weebly.com/gender-di fferences.html. Retrieved on 25/8/2020

[23] Maryam, H. \& Sarayya, B. Directed Reading and Thinking Activity and Reading Comprehension The Journal of English Language Pedagogy and Practice. Vol.11, No.22, pp. 111-126, Spring and Summer 2018. http://jai.iaut.ac.ir/articl e_541068html.

[24] McLeod, S. Social Learning Theory. www.simplypsycholo gy.org/bandura.html. Retrieved on 18/1/2020

[25] McMillan, J. H. \& Schumacher, S. Inferential Statistics. Research in education: A conceptual introduction. $2^{\text {nd }}$ Edition. New York: Harper Collins Publications.1989 (361-366)

[26] Nord Anglia Education. The Importance of Reading. http://www.nordangliaeducation.com. Retrieved on $27 / 3 / 2021$

[27] Odwan, A. R. The Effect of Directed Reading and Thinking Activity through Cooperative Learning on English Secondary Stage Students Reading Comprehension in Jordan. International Journal of Humanities and Social Sciences. Vol.2 No.16. pp. 138-151. 2012 www.ijhssnet.com.>Vol_2_No_16_Issue_August_2012

[28] Ornstein C, A. Strategies for Effective Teaching $2^{\text {nd }}$.Chicago: Brown \& Benchmark. 2001(169-172)

[29] Price. J. Classroom Management and Behavior Strategy, Cited in Denby .J (Editor). Training to Teach, $2^{\text {nd }}$ Edition. SAGE, 2012. Pp. 95-101

[30] Rae, B. Pictures Cues and Reading Comprehension: Impact of Picture Cues on the Reading Comprehension of First Grade Students with Autism Spectrum Disorder. https//fisherpub.sjfc.edu/education. Retrieved on 23/10/1019.

[31] Regoli, N. 18 Simple Random Sampling Advantages and
Disadvantages.

https://connectusfund.org>18-simple-random-sampling-adv antages-and-disadvantages. Retrieved on 2/12/2020

[32] Renn, C. E. The Affects of the Directed Reading and Thinking Activity in Second Grade Reading Comprehension. htt://scholarworks.gvsu.edu/theses/content=thesis456 Retrieved on April 3.2019

[33] Sandhu, R. What is Reading- Definition and Process. http:/study.com/academy/lesson/what-is-reading-defination -process.html. Retrieved on January 7.2020

[34] Saqid, M.. Use of Photographs as a Powerful Tool in Teaching/ Learning Environment: An Experience. EDULEARN, Proceedings, pp. 1788-1792 https://library.iated/view/SADIQ2013USE. Retrieved on $17 / 3 / 2021$

[35] Stephen Perse Foundation. Teaching Methods: Traditional Vs Modern. https://sixthformstephenperse.com/blog/?7pid= 458. Retrieved on $13 / 4 / 2021$

[36] Torgesar, J. Houston, J. Rissaman, L \& Kosanvich, M. Teaching all Students to Read in Elementary School: Guide for Principals. NH.RMC. Research Corporation Center on Instruction. www.centeroninstruction.org. Retrieved on $13 / 10 / 2020$

[37] UNESCO REPORT. Teaching Reading in Primary Schools. http://www.uis.unesco.org. Retrieved on 3/9/2019

[38] VanVoorhis, C.R.W. \& Morgan, B.L. Understanding Power and Rules of Thumb for Determining Sample Size. Tutorials in Quantitative Methods for Psychology. Vol. 3(2). pp. 43-50, 2007. DOI:10.20982/tqmp.03.2.p043.

[39] Wallah, B. W. Kiswahili Mufti: Darasa la Nne. Nairobi: Longhorn Publishers. 2014 (67-68)

[40] Yuliana F. The Effect of DRTA and Reading Interest on Student's Reading Comprehension. Repository. http://.uinjkt.ac.id/dspace/bitstream/123456789/28357/1/FR ISKAYULIANA-FITK.pdf. Retrieved on January 29.2019 